\title{
BS II Lectin: A Second Hemagglutinin Isolated from Bandeiraea Simplicifolia Seeds with Affinity for type III Polyagglutinable Red Cells
}

\author{
W.J.Judd, M. L. Beck, B. L. Hicklin, P.N. Shankar Iyer and I. J. Goldstein \\ Departments of Pathology and Biological Chemistry, University of Michigan, Ann Arbor, Mich., and \\ Community Blood Center of Greater Kansas City, Kansas City, Mo.
}

\begin{abstract}
BS II lectin, a second hemagglutinin isolated from Bandeiraea simplicifolia seeds, agglutinated the red cells from 11 patients manifesting the 'acquired B' antigen phenomenon. The results of serological studies indicate that this lectin has specificity for the type III polyagglutinable receptors rather than for the 'B-like' antigens present on 'acquired B' red cells.

Two other blood samples which did not possess 'acquired B' antigens were also found to react with BS II lectin. Both of these samples were shown to have properties similar to those reported for Tk red cells. The serological characteristics of red cells modified in vitro by a culture broth of Bacteroides fragilis suggest that type III polyagglutinable receptors are identical to those associated with Tk red cells.
\end{abstract}

\section{Introduction}

Mäkelä and Mäkelä [9] reported anti-B hemagglutinating activity in saline extracts of Bandeiraea simplicifolia seeds. Hayes and Goldstein [4] isolated from these seeds an $\alpha$ - $D$-galactosyl binding lectin, BS I, having a high affinity for group B red blood cells [8]. Iyer et al. [6] have now isolated a further lectin from $B$. simplicifolia seeds, designated BS I (G1cNAc lectin), which has a primary specificity for $N$-acetyl- $D$-glucosamine.

In serological tests BS II lectin failed to react with a large number of donor blood samples having normal ABO phenotypes, but did agglutinate the red cells from 11 'acquired B' blood samples as well as those from 2 patients who had not acquired ' $B$ like' antigens. Bacteroides fragilis was isolated by blood culture from one of these patients.

B. fragilis has recently been implicated in inducing Tk red cell polyagglutination [5]. We have studied red cells modified by this organism in vitro. Our results indicate that the type III polyagglutinable receptors present on 'acquired B' red cells [1] are identical to those that define $\mathrm{Tk}$ polyagglutination. 


\section{Materials and Methods}

BS II lectin was isolated from B. simplicifolia seeds by affinity chromatography on chitin as previously described [6] and diluted to an initial concentration of $0.4 \mathrm{mg} / \mathrm{ml}$ with $22 \%$ bovine albumin. Bovine albumin was also used as the diluent in titration studies. Agglutination tests were performed by adding $1 \mathrm{vol}$ of a $5 \%$ saline suspension of washed red cells to $2 \mathrm{vol}$ of lectin. Following incubation at $4^{\circ} \mathrm{C}$ for $1 \mathrm{~h}$ the tests were centrifuged at $1,000 \mathrm{~g}$ for $15 \mathrm{sec}$ and examined macroscopically. Agglutination reactions were scored according to the method of Race and Sanger [10]. Sugar inhibition studies were carried out with $0.1 M$ solutions of the various sugars in phosphate-buffered saline at $\mathrm{pH}$ 7.3. Details of other serological techniques have been presented elsewhere [7].

\section{Results}

\section{Serological Specificity of BS II Lectin}

BS II lectin did not agglutinate the red cells from 48 group $O, 52$ group $A_{1}, 18$ group $A_{2}, 36$ group $B$ or 43 group $A B$ donor blood samples. Red cells with uncommon phenotypes within the $A B O, P$, MNSs and rhesus blood group systems were also nonreactive. Weak reactions (titer 2, score 8) were encountered with protease or neuraminidase (Vibrio cholerae)-treated red cells, as well as with the polyagglutinable red cell types $\mathrm{Tn}$ and Cad 2. A blood sample from a patient having acquired ' $B$-like' antigens was found to be strongly reactive with BS II lectin. These results are summarized in table I.

10 further examples of 'acquired B' red cells were tested with BS II lectin. Although initially only 4 reacted, all did so following ficin treatment (table II). No such enhancement was observed following ficin treat-
Table 1. Reactions of 'normal' and selected red cell phenotypes with BS II lectin

Non-reactive

$\mathrm{O}(48), \mathrm{A}_{1}(52), \mathrm{A}_{2}(18), \mathrm{B}(36)$

$\mathrm{AB}(43), \mathrm{Oh}(3), \mathrm{A}_{\mathbf{x}}(5), \mathrm{B}_{\mathrm{m}}(1)$

$A_{1} B_{m}(1), \operatorname{Tj}(a-)(3)$

$P_{1}{ }^{k}(1), U$ neg(6), $R h_{\text {null }}(3)$

Weakly reactive (titer 2 , score 8)

Protease-treated (all ABO types)

Neuraminadase-treated (all ABO types)

$\operatorname{Tn}(3), \mathrm{Cad} 2(2)$

Strongly reactive (titer 32, score 47)

'Acquired B' red cells(1)

Figures in parentheses indicate the number of each cell type tested.

ment of normal, Tn, Cad 2 or neuraminidase-treated ( $\mathrm{T}$-activated) red cells.

An additional 236 blood samples submitted to the blood bank were tested, and the red cells from 2 patients, Mrs. L (group $A_{1}$ ) and Mrs. M (group B), were strongly agglutinated by BS II lectin. Although these red cells had not acquired 'B-like' antigens they were polyagglutinable. $B$. fragilis was isolated from a blood culture of Mrs. $M$.

\section{Studies on B. fragilis-Modified}

\section{Red Cells}

Normal red cells were modified with the supernatant from the blood culture obtained from Mrs. M, and tested with BS II and Arachis hypogoea lectins. The results of these tests are shown in table III. The modified red cells reacted strongly with BS II lectin and weakly with $A$. hypogoea. Treatment of the modified red cells with ficin resulted in marked enhancement of agglutination by both reagents, in contrast to the 
Table II. Reactions of eleven examples of 'acquired B' red cells with BS II lectin

\begin{tabular}{|c|c|c|c|c|c|c|c|c|c|c|c|c|c|}
\hline & \multicolumn{13}{|c|}{ Case No. } \\
\hline & 1 & 2 & 3 & 4 & 5 & 6 & 7 & 8 & 9 & 10 & 11 & A & B \\
\hline \multicolumn{14}{|c|}{ Untreated } \\
\hline Titer & 16 & 0 & 16 & 0 & 8 & 32 & 0 & 0 & 8 & 0 & 0 & 0 & 0 \\
\hline Score & 32 & 0 & 34 & 0 & 31 & 47 & 0 & 0 & 20 & 0 & 0 & 0 & 0 \\
\hline \multicolumn{14}{|c|}{ Ficinized } \\
\hline Titer & 512 & 32 & 512 & 8 & 256 & 512 & 8 & 4 & 128 & 8 & 16 & 2 & 2 \\
\hline Score & 98 & 42 & 96 & 24 & 82 & 100 & 21 & 18 & 76 & 31 & 32 & 8 & 8 \\
\hline
\end{tabular}

Table III. Results of titration studies on 'acquired B' red cells and red cells modified by B. fragilis with BS II and $A$. hypogoea lectins

\begin{tabular}{|c|c|c|c|c|}
\hline & \multicolumn{2}{|l|}{ BS-2 lectin } & \multicolumn{2}{|c|}{ A. hypogoea } \\
\hline & untreated & ficinized & untreated & ficinized \\
\hline $\mathrm{O}$ & 0 & 0 & 0 & 0 \\
\hline$A_{1}$ & 0 & 2 & 0 & 2 \\
\hline B & 0 & 2 & 0 & 2 \\
\hline $\mathrm{O}(\mathrm{BF})$ & 64 & 16,000 & 32 & 256 \\
\hline$A_{1}(B F)$ & 128 & 32,000 & 64 & 512 \\
\hline $\mathrm{B}(\mathrm{BF})$ & 64 & 16,000 & 32 & 256 \\
\hline Mrs. L & 32 & 4,000 & 32 & 128 \\
\hline Mrs. M & 16 & 1,000 & 8 & 64 \\
\hline \multicolumn{5}{|l|}{ 'Acquired B' } \\
\hline 1 & 16 & 512 & 4 & 32 \\
\hline 2 & 16 & 512 & 8 & 64 \\
\hline 3 & 8 & 256 & 2 & 16 \\
\hline 4 & 32 & 512 & 16 & 128 \\
\hline 5 & 8 & 128 & 4 & 32 \\
\hline T-activated ${ }^{a}$ & 2 & 2 & 4,000 & 512 \\
\hline
\end{tabular}

Tests performed at $4^{\circ} \mathrm{C}$ for $1 \mathrm{~h} . \mathrm{BF}=$ Cells treated with $B$. fragilis culture broth.

a Neuraminidase-treated. 
results obtained following ficin treatment of neuraminidase-treated ( $\mathrm{T}$-activated) red cells.

The results of tests with BS II lectin and A. hypogoea on the red cells from Mrs. L and Mrs. M are also shown in table III. Ficin treatment of these cells resulted in enhancement of agglutination, similar to that observed following ficin treatment of the $B$. fragilis-modified red cells.

The red cells of Mrs. L, Mrs. M and red cells modified in vitro by the $B$. fragilis culture broth were shown to have properties similar to those reported for Tk red cells [5]. Agglutination in group AB serum was enhanced by ficin. There was no agglutination in $A$. hypogoea which had been absorbed with neuraminidase-treated red cells. Aggregation in Polybrene was normal. The sera of Mrs. L and Mrs. M contained normal quantities of anti-T.

Group $A_{1}$ red cells were treated with the $B$. fragilis culture broth and tested by absorption and elution techniques with group A sera and commercial anti-B reagents. No evidence for the acquisition of 'B-like' antigens could be demonstrated on these modified red cells.

\section{Demonstration of Tk Receptor on 'Acquired B' Red Cells}

Table III also shows the results of tests with $A$. hypogoea on the red cells from 5 'acquired B' blood samples. All were weakly agglutinated by $A$. hypogoea, and the reactions were enhanced by ficin. Agglutination of these 'acquired $\mathrm{B}$ ' samples in group $\mathrm{AB}$ serum was also enhanced by ficin, and the red cells from each case were found to aggregate in Polybrene. Absorption of group $\mathrm{AB}$ serum with red cells modified by the $B$. fragilis culture broth completely removed its activity for all five samples. The sera from these 'acquired B' bloods contained anti-T.

\section{Inhibition Studies on BS II Lectin}

The extent to which various sugars inhibited the hemagglutinating activity of BS II lectin was studies. $N$-acetyl- $D$-glucosamine inhibited the agglutination of all reactive red cell samples, including those modified by $B$. fragilis in vitro.

No inhibition was observed with lactose, $D$-galactose, $D$-glucose, $N$-acetyl- $D$-mannosamine or with $N$-acetyl- $D$-galactosamine. Saliva samples (secretor and non-secretor), purified $A$ and $B$ substances, and hydatid cyst fluids also were non-inhibitory.

\section{Discussion}

According to Gerbal et al. [3] the 'acquired-B' antigen phenomenon arises from the action of a deacetylase, produced by certain strains of Escherichia coli. This enzyme transforms $N$-acetyl- $D$-galactosamine on group $A_{1}$ cells into $D$-galactosamine which cross-reacts with human anti-B reagents. It is evident, however, that BS II activity with 'acquired B' cells is not directly related to bacterial deacetylation for the following reasons. First, 2 patients' blood samples, one of which was group $A_{1}$, reacted strongly with BS II lectin but did not exhibit the 'acquired B' antigen phenomenon. Second, the supernatant broth from a culture of $B$. fragilis did not transform $\mathrm{A}_{1}$ red cells into 'acquired $B$ ' red cells, although these modified red cells reacted strongly with BS II lectin. Finally, BS II lectin is inhibited by $N$-acetyl- $D$-glucosamine but not by $N$-acetyl- $D$-galactosamine or $D$-galactose, 
the $\mathrm{A}$ and $\mathrm{B}$ immunodominant sugars, respectively.

An enzyme produced by certain strains of $B$. fragilis has been implicated by Inglis et al. [5] in causing Tk polyagglutinability. We have demonstrated that BS II lectin reacts with red cells modified in vitro by the supernatant from a broth culture of this organism, and Bird [2] found that BS II lectin reacted with in-vivo-induced $\mathrm{Tk}$ red cells. It is therefore our contention that BS II lectin recognizes the Tk polyagglutinable receptor.

The results of studies on the polyagglutinable red cells of Mrs. L, Mrs. M and the 'acquired B' blood samples indicate that these cells possess Tk receptors. Of particular significance is the observation that the agglutinins in group $\mathrm{AB}$ sera, which react with 'acquired B' red cells, are absorbed by red cells modified in vitro by $B$. fragilis.

Bird [2] also observed that BS II lectin reacts with red cells $\mathrm{T}$-activated in vivo. This is especially significant since we were unable to demonstrate any appreciable activity of BS II lectin for red cells modified by neuraminidase in vitro. This suggests that certain neuraminidase-producing organisms are capable of exposing the $\mathrm{Tk}$ receptor in vivo. An alternative explanation is that more than one enzyme, each of a different bacterial origin, acts simultaneously or sequentially to modify the red cell membrane in vivo. Thus, in certain group $A_{1}$ individuals a bacterial deacetylase produces the 'acquiredB' antigen, while another enzyme, possibly from $B$. fragilis, exposes the Tk receptor. In those group A patients whose red cells are not susceptible to the action of bacterial deacetylase, for reasons given by Gerbal et al. [3], and in group $\mathrm{O}, \mathrm{B}$ or $\mathrm{AB}$ in- dividuals, the $B$. fragilis enzyme alone produces modification resulting in the exposure of Tk polyagglutinable receptors.

Beck et al. [1] proposed that the polyagglutination observed with 'acquired B' red cells be termed 'type III'. In view of the similarity between the polyagglutinable properties of both Tk and 'acquired B' red cells, we suggest that $T k$ polyagglutination be redesignated as type III.

The results of inhibition studies on BS II lectin suggest that $N$-acetyl- $D$-glucosamine is involved in the structure of the TK receptor. The nature of the $B$. fragilis enzyme remains ill-defined and is the subject of current study.

\section{Acknowledgements}

This study was supported in part by NIH grants AM 10171. We wish to express our thanks to $\mathrm{Mr}$. J.Moulds, Miss K. Beattie and Mrs. B. Sabo for supplying some of the 'acquired B' blood samples used in this study. We are indebted to Dr. G.W.G. Bird for studying his cases of $T k$ polyagglutinable red cells with BS II lectin. We also wish to acknowledge the technical assistance of $\mathrm{Mr}$. $J$.Bashforth for supplying the B.fragilis culture broth.

\section{References}

1 Beck, M. L.; Walker, R.H., and Oberman, H. A.: Atypical polyagglutination associated with an acquired-B antigen. Transfusion 11: 296 (1971).

2. Bird, G. W. G.: Personal commun. (1975).

3 Gerbal, A.; Maslet, C., and Salmon, C.: Immunological aspects of the acquired-B antigen. Vox Sang. 28: 398 (1975).

4 Hayes, C. E. and Goldstein, I. J.: An $\alpha$-Dgalactosyl binding lectin from Bandeiraea simplicifolia seeds. J. biol. Chem. 249: 1904 (1974). 
5 Inglis, G.; Bird, G. W. G.; Mitchell, A. A. B.; Milne, G. R., and Wingham, J.: Erythrocyte polyagglutination showing properties of both $\mathrm{T}$ and Tk probably induced by Bacteroides fragilis infection. Vox Sang. 28: 314 (1975).

6 Iyer, P. N.; Wilkinson, K., and Goldstein, I. J.: An $N$-acetyl- $D$-glucosamine binding lectin from Bandeiraea simplicifolia seeds. Archs Biochem. Biophys. 177: 330 (1976).

7 Judd, W. J.: A bromelin dependent panagglutinin. Vox Sang. 25: 166 (1973).

8 Judd, W. J.; Steiner, E. A.; Friedman, B. A.; Hayes, C. E., and Goldstein, I. J.: Serological studies on an $\alpha$-D-galactosyl binding lectin isolated from Bandeiraea simplicifolia seeds. Vox Sang. 30: 261 (1976).

9 Mäkelä, O. and Mäkelä, P.: Some new blood group specific phytagglutinins. Annls Med. exp. Biol. Fenn. 34: 402 (1956).

10 Race, R. R. and Sanger, R.: Blood groups in man (Blackwell, Oxford 1958).

Accepted: November 23, 1976

Mr. W. J. Judd, Department of Pathology, University of Michigan, 1335 E. Catherine St., Ann Arbor, MI 48109 (USA) 